\title{
LANGUAGE, IDENTITY AND RELATIONALITY IN ASIAN PACIFIC AMERICA ${ }^{1}$ : AN INTRODUCTION ${ }^{2}$
}

\author{
Adrienne Lo and Angela Reyes
}

\section{Invisibility of Asian Pacific Americans in language research}

Relative to other racial and ethnic groups in the US, Asian Pacific Americans (APAs) have received comparatively little attention from scholars in linguistic anthropology. Whereas the language practices of African Americans have been of abiding interest to linguistic anthropologists, sociolinguists, and dialectologists since the 1970s (e.g., Baugh 1983; Kochman 1981; Labov 1972; Mitchell-Kernan 1972; Morgan 2002) and significant bodies of work on Latinos (e.g., Bailey 2002; Fought 2003; Penfield and Ornstein-Garcia 1985; Zentella 1997) and Native Americans (e.g., Basso 1979; Kroskrity 1993; Leap 1993; Philips 1983) form a longstanding tradition, linguistic anthropological work on Asian Pacific Americans outside of Hawai'i has yet to receive the same kind of sustained scholarly attention as other racial and ethnic groups in the

${ }^{1}$ We use "Asian Pacific American” (APA) as a superordinate term that includes people in the US of Asian descent, such as East Asian (e.g., Korean, Chinese), Southeast Asian (e.g., Cambodian, Laotian) and South Asian (e.g., Indian) descent, as well as people in the US of Pacific Islander descent (e.g., Micronesian, native Hawaiian). We recognize that APA is a socially constructed term that can dangerously assume some a priori essence of a homogeneous, monolithic grouping with clearly distinguished boundaries, presenting a reified vision of unity and stability while papering over issues of diversity and murky borders (see Espiritu 1992 for a classic discussion of panethnicity). We are also aware of the controversy that the term "Asian Pacific American” generates, particularly in light of recent debates over the 2004 initiative to change the name of the Association of Asian American Studies to Association of Asian/Pacific Islander American Studies. (This resolution was eventually withdrawn from the ballot.) We respectfully use the term APA for this Special Issue because the papers by Talmy and Labrador deal not only with Asian Americans in Hawai'i, but also with native Hawaiians, people of "mixed" Asian and Pacific Islander heritage, and immigrants from the Marshall Islands, Chuuk and the Philippines (the Philippines being a not uncontentious member of the Pacific Islands). We hope that these two papers in particular contribute to the continuing discussion which surrounds the term "Asian Pacific American" through their critical examination of the linkages and tensions within and among the constructed boundaries of Asian American and Pacific Islander communities.

2 This issue developed from two sessions at the AAA conference in 2002 and 2003 . We would like to thank the discussants and attendees at those sessions for their encouragement of this work, especially Barbara Johnstone and John Rickford. Preparation of this article, which represents the equal work of both authors, was supported by grants from the UCLA Asian American Studies Center, the Spencer Foundation, the University of California Linguistic Minority Research Institute (UC LMRI) under the UC LMRI Grants Program, the Ford Foundation, and the University of Pennsylvania Graduate School of Education. Opinions reflect those of the authors and do not necessarily reflect those of the grant agencies. We would also like to thank Steven Talmy and Elaine Chun for their generous comments on an earlier version of this article. 
US. ${ }^{3}$ Although scholars working in Canada, the UK, and Australia have produced key monographs on the language practices of second and third generation Asians in those countries (Li 2002; Nishimura 1997; Rampton 1995; Tuc 2003; Wei 1994), here in the US we still lack such major book-length treatments on APAs outside of Hawai'i. ${ }^{4}$ Given that Asian Pacific Americans constitute one of the fastest growing segments of the US population, with a population of over 12 million according to the 2000 census (Lai and Arguelles 2003: 2), ${ }^{5}$ why have they not garnered more attention from scholars?

We offer a few reasons for why Asian Pacific Americans have been relatively absent from language and ethnicity research in the US. APAs have been uniquely racialized by pervading US discourses in ways that have shaped both popular as well as scholarly perspectives. As Tuan (1998) notes, APAs tend to be pigeonholed as either "forever foreigners" or as "honorary whites." The "forever foreigner" viewpoint is reflected by the fact that research on APAs to date has tended to foreground issues of heritage language maintenance (e.g., Ching and Kung 1997; Cho, Cho and Tse 1997; Sridhar 1988) and codeswitching (e.g., Shin and Milroy 2000; Yoon 1996) while giving relatively short shrift to the ways in which English is often a primary medium of communication (see Bailey 1997, 2000; Chun 2001; Kang and Lo 2003; Reyes 2002 for exceptions). Some researchers of heritage languages, for example, look at APA language practices from an explicitly comparative deficit perspective. By emphasizing the ways in which APAs' heritage language practices fall short of "authentic" native speakers in Asia and the Pacific, some work positions APAs as inadequate "forever foreigners." Moreover, it is not uncommon for researchers to look at APAs living in the US as though they were monolingual (and monocultural) speakers of their heritage languages. Thus, we find scholars who look at the acquisition or functional grammar of Asian and Pacific Islander languages using Asian Pacific American subjects with little attention paid to their bilingual or bicultural context. While this is seen as perfectly acceptable, it is difficult to imagine a parallel case in which a scholar wanting to study the acquisition or use of French would choose all of their subjects from Parisian émigrés in New York, as though living in the United States would not make their language practices fundamentally different from those of monolingual French speakers living in France. The image of APAs as living in cloistered ethnic enclaves, somehow separate and apart from the rest of American society, legitimates scholars' depiction of Asian Pacific Americans as the repositories of some fundamentally unchanging "Asian" (or "Samoan," etc.) essence (Ong and Nonini 1997).

The "forever foreigner" image co-exists alongside a contradictory "honorary white" viewpoint, which is equally problematic in that it assumes all APAs assimilate to some idea of the white middle-class mainstream in a way that erases their racial status. This perspective argues that there is nothing interesting or distinct about APAs since they just exemplify another case of the American "melting pot" and over a generation or two become equivalent to "white" mainstream English speakers. This stereotype ignores both the well-documented examples of racism that greets APAs in communities which

\footnotetext{
${ }^{3}$ See the bibliography at the end of this Special Issue for a selection of work in this area.

${ }^{4}$ Research on Hawai'i Creole and the politics of language in Hawai'i has been robust. See Reinecke (1969), Romaine (1999, 2002), and Sato (1985, 1991), among others.

${ }^{5}$ Between 1990 and 2000, the APA population in the US increased 72 percent. The total US population growth during that time was 13 percent. According to the latest census projections, the number of APAs is expected to reach 33 million by 2050.
} 
are suddenly "flooded" by them ${ }^{6}$ as well as the ways in which non-middle-class and non-East Asian APAs may not be assimilating to middle class white norms of spoken English (see Bucholtz, this issue; Zhou and Bankston 1998; Reyes, this issue).

The central issue here is that APAs do not seem to fit the models of language and ethnicity that have dominated sociolinguistic research in the US (see Bucholtz, this issue). Research on other linguistic minorities has focused on describing and analyzing phonological, syntactic and other linguistic patterns which define ethnically distinct varieties of American English, such as African American Vernacular English (AAVE) or Chicano English. These models presume that there is some kind of isomorphic mapping between a linguistically distinct form of English and a racially distinct group. While a highly stereotyped version of Mock Asian does seem to circulate across media contexts (see Chun, this issue), the English of APAs - as opposed to the English of other American ethnic and racial groups - is socially constructed in different ways. First, the English that APAs speak is usually recognized not as a distinct dialect, but often as some kind of "accent" which is seen as the product of foreign language interference. Second, while certain features of the English that US-raised APAs speak may be different from Mainstream American English (MAE), these features do not seem to enjoy the same kind of widespread recognizability that features of AAVE or Chicano English do. The fact that many second generation APAs can speak MAE only seems to lend further credence to the stereotype that American-born APAs are linguistically, as well as ethnically, assimilated to white American norms.

This racial positioning thus leads to three simultaneously contradictory trends. First, APAs are situated as fundamentally Asian in ways that erase their membership in American society. Also, second and later generation APAs are seen as linguistically and culturally assimilated to middle class white norms. Lastly, APAs are often positioned by scholars as well as by members of their ethnic communities as "inauthentic" speakers of heritage languages, evaluated by the deficiency of their linguistic practice when measured against "real” native speakers.

\section{Previous research on Asian Pacific American linguistic practices}

Early sociolinguistic research on mainland APAs includes Robert Spencer's (1950) article in American Speech on the English of Japanese American nisei. Based on his research in internment camps, this work outlines the phonological, morphological, and syntactic features of the speech of second generation Japanese Americans. Spencer points out that the distinctive patterns of English that he observed are not so much the product of a "foreign accent" as they are reflective of the social isolation that many nisei faced. Several studies have found that participants do not seem to be able to identify either first or second generation APAs as APA based exclusively on listening to taperecordings of their English (Hanna 1997; Lindemann 2003; Mendoza-Denton and Iwai 1993). The experimental methods used in these elicitation studies have not generally been successful in disentangling the complex issues surrounding the English that APAs speak. These include: 1) in what situations and with whom do APAs speak a version of English which is different from MAE?; 2) what are the features of this English?; 3) is

\footnotetext{
${ }^{6}$ See Crawford (1992: 1-11 and 136-147) for discussions of linguistic racism in Monterey Park, CA and Lowell, MA.
} 
this variety identifiable as indexing a particular ethnic or racial identity; and 4) if so, who recognizes it as such?

Another body of work examining APA linguistic practices is codeswitching. One of the earliest studies is Susan Ervin-Tripp's (1964) article in the Special Issue of the American Anthropologist edited by John Gumperz and Dell Hymes on the speech of Japanese war brides married to American servicemen. Ervin-Tripp examined the ways in which Japanese American women invoke different topics when speaking in English or Japanese to American or Japanese interlocutors. Work on codeswitching continues to be one of the more productive areas of inquiry, with bodies of work on codeswitching among Vietnamese Americans (Kleifgen 2001), Korean Americans (Ha 1995; Kang 2003; Lo 1999; Shin and Milroy 2000; Yoon 1992, 1996) and Japanese Canadians (Nishimura 1997).

Issues in heritage language learning, literacy, and second language learning among APAs have also attracted a great deal of attention from researchers. Hinton (2001) provides a comprehensive overview of APA college students' attitudes towards their heritage language, while the heritage language learning of Chinese Americans (He 2001), Korean Americans (Jo 2001) and Japanese Americans (Kondo 1998) has received much attention as well. Literacy practices have been documented among Hmong Americans (Weinstein-Shr 1993), Khmer Americans (Hardman 1998; Needham 2003, Skilton-Sylvester 2002), Laotian Americans (Fu 1995), native Hawaiians ( $\mathrm{Au}$ 1980; Au and Jordan 1982), Samoan Americans (Duranti and Ochs 1997; Duranti, Ochs and Ta`ase 1995), Korean Americans (Scarcella and Chin 1993), Filipino Canadians (Li

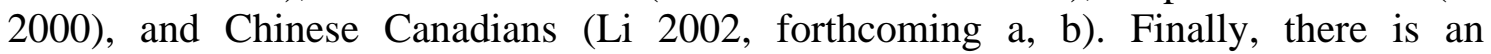
abundance of work in second language studies examining English language learning among Asian immigrants in several locales, including the mainland US (e.g., Chiang and Schmida 1999; Hakuta 1975; Harklau 1994), Hawai‘i (e.g., Schmidt 1983), and Canada (e.g., Duff, Wong and Early 2002; Pon, Goldstein and Schecter 2003).

\section{Relationality}

Taking as its starting point the research on APA linguistic practices mentioned above, this Special Issue attempts to reposition the linguistic anthropology of APAs by considering the ways in which APA identities are produced relationally, through systems of opposition (Barth 1969). Scholars in the structuralist tradition such as Saussure and Jakobson have long realized that we only come to know what something is by how it is relationally positioned against other things. By taking a discursive approach which examines how identities are locally constituted in conjunction with ideologies of ethnic and racial positioning, we seek to problematize essentialist approaches that equate APA identity with speaking either a heritage language or an ethnically marked form of English. Instead, the papers in this collection look at how such identities only exist and become identifiable as they locally emerge in relation to other identities. There is no Asian Pacific American without Caucasian American, no African American without Latino, no self without the other. This focus on the situated and relational unfoldings of identity reveals how participants position themselves with regard not only to each other, but also to the ways in which they are defined by discourses of race and ethnicity which circulate through mass media, institutions and everyday contexts. 
One important theme of this Special Issue involves the ways in which APAs define themselves in relation to dominant racializing ideologies. The image of the immigrant, foreigner, or $\mathrm{FOB}^{7}$ is a complex one which serves as a touchstone against which identities are constructed. On a linguistic level, the lens of the indelible foreign "accent" shapes the ways in which the linguistic practices of second and later generation APAs are construed. As Talmy's paper shows, differentiating oneself from more newly arrived FOBs is a key social practice for immigrant youth in a Hawai'i high school who use Pidgin to underscore both the long history of their childhood socialization in Hawai'i and their affiliation as "Local." Having a distinctively foreign "accent" is likewise a central stigmatizing feature in the racist depiction of Filipinos in the discourse of local comedians in Hawai'i described by Labrador. Both Labrador's and Chun's papers explore ideologies of humor and race which license second and later generation comedians and their audiences to instantiate a hierarchy of differentiation (Bucholtz and Hall 2004) by mocking the linguistic practices of those with a foreign accent. The complex patterns of voicing they describe reveal how mockery can simultaneously contest, appropriate and reify the indexical links between a stigmatizing accent and the image of the foreigner.

The papers also highlight the multifaceted ways in which APA speakers orient themselves with respect to particular types of ethnic communities. While Shankar's paper highlights the ways in which Bollywood films ${ }^{8}$ serve as an empowering resource for desi youth, providing them with frameworks for understanding their own lives, Kang, He, and Lo's papers show how cleavages of identity operate even within what might be considered a single ethnic community. Kang's paper illustrates how participants at a Korean American camp carefully situate themselves within a field of oppositions, locally defining self and others as "American," "Korean," and "Korean American." He's paper demonstrates how teachers and students in a Chinese heritage language classroom use pronouns to index their co-membership but also to contrastively demarcate affiliations with different institutions. Lo's paper looks at how a Korean American teacher's use of evidential marking situates her students as opposing moral types. In each of these cases, participants' identities as "Chinese American" or as "second generation" are not overarching sui generis categories, but instead are indexically emergent in ways which link them to ideologies and practices. In contrast with approaches which limit their depiction of APA identity to demographic categories (e.g. place of birth, generation, length of residence), we seek instead to show how participants themselves negotiate which particular categories become relevant in the moment of speaking.

One key point is that invocation of APA identities does not necessarily rely upon either speaking a heritage language or an ethnically distinct version of English. The papers in this collection detail various ways in which speakers categorize themselves and others. While this is sometimes accomplished through the invocation of explicit forms of self-categorization, as in Kang's paper, other indexical links between accents, stereotypes, and recognizable genres of practice are also crucial. Shankar's paper, for example, demonstrates how a seemingly non-referential cough is transformed by Silicon Valley teenagers into a Bollywood quote through creative recontextualization. Socially recurrent activities like the teasing of FOBs by more English proficient classmates in

\footnotetext{
7 FOB is an acronym or initialism of "Fresh Off the Boat," a derogatory label for an unacculturated Asian immigrant newly arrived to the US.

${ }^{8}$ Bollywood films are films produced and distributed in Bombay (Mumbai), India.
} 
the classroom studied by Talmy help to reinscribe the indexical links between activity, linguistic forms, and categories of identity.

We also hope that this collection will forge new ground in showing how participants invoke wider social discourses in the micro-interactional details of practice. Several of the papers consider how participants define their identities in relation to stereotypes which circulate both through the media and through local discursive chains (Agha 2003). Bucholtz's paper, for example, describes how two Laotian American teens position themselves with relation to the "model-minority nerd" and more recent "gangster" stereotype of Asian Americans. By using the locally available resources of AAVE and youth slang, these girls find ways to position themselves between the school's binary black/white dichotomy, showing how APAs can carve out a distinct social space even in the absence of an ethnically distinctive dialect of English. Reyes' paper reveals the complex ways that teens at a youth center orient to both locally and widely circulating stereotypes about Asians. Reyes shows that teens can both resist as well as embrace stereotypes as resources for identity making.

Finally, what categories of identity are relevant in any case and how they are indexed is an open question that relies on the principle of relationality. Race and ethnicity in APA communities intersect with other important social categories, like gender, (Chun, and Labrador, this issue), sexuality (Manalansan 1995), class (Labrador, this issue), and institutionalized identities like teacher and student which give participants different degrees of power and control over identity-making (He, Lo, and Talmy, this issue). The category of APA itself is highly contested and while some speakers do orient to explicit notions of what is "Asian” (see Reyes, this issue), in grouping these papers together we do not claim that they form some kind of cohesive "Asian Pacific American speech community.” Instead, we hope that this collection will contribute to theoretical debates within linguistic anthropology by showing the different ways that APAs index complex identities that go beyond binary black/white paradigms of race. Since APAs are uniquely positioned as both assimilated and foreigner, analyzing the "multiplicity" (Lowe 1996) of APA identities as relationally produced can elucidate how racial, ethnic, institutional, and national boundaries are constructed through the medium of language.

\section{References}

Agha, Asif (2003) The social life of cultural value. Language and Communication 23: 231-273.

Au, Kathryn Hu-Pei (1980) Participation structures in a reading lesson with Hawaiian children: Analysis of a culturally appropriate instructional event. Anthropology and Education Quarterly 11.2: 91- 115.

Au, Kathryn Hu-Pei, and Cathie Jordan (1982) Teaching reading to Hawaiian children: Finding a culturally appropriate solution. In Henry T. Trueba, Grace Pung Guthrie and Kathryn Hu-Pei Au (eds.), Culture and the bilingual classroom: Studies in classroom ethnography. Rowley, MA: Newberry House Publishers, pp. 139-152.

Bailey, Benjamin (1997) Communication of respect in interethnic service encounters. Language in Society 26.3: 327-356.

Bailey, Benjamin (2000) Communicative behavior and conflict between African-American customers and Korean immigrant retailers in Los Angeles. Discourse and Society 11.1: 86-108. 
Bailey, Benjamin H. (2002) Language, race, and negotiation of identity: A study of Dominican Americans. New York: LFB Scholarly Pub.

Barth, Frederik (1969) Introduction. In Frederik Barth (ed.), Ethnic groups and boundaries: The social organization of cultural difference. Bergen-Oslo: Universitets Forlaget, pp. 9-39.

Basso, Keith H. (1979) Portraits of "the whiteman": Linguistic play and cultural symbols among the western Apache. Cambridge; New York: Cambridge University Press.

Baugh, John (1983) Black street speech: Its history, structure, and survival. Austin: University of Texas Press.

Bucholtz, Mary, and Kira Hall (2004) Language and identity. In Alessandro Duranti (ed.), A companion to linguistic anthropology. Oxford: Basil Blackwell, pp. 369-394.

Chiang, Yuet-Sim D., and Mary Schmida (1999) Language identity and language ownership: Linguistic conflicts of first-year university writing students. In Linda Harklau, Kay M. Losey and Meryl Siegal (eds.), Generation 1.5 meets college composition: Issues in the teaching of writing to U.S.-educated learners of ESL. Mahwah, NJ: Lawrence Erlbaum Associates, pp. 81-96.

Ching, Marvin K.L, and Hsiang-te Kung (1997) Ethnic identity, Americanization, and survival of the mother tongue: The first- vs. the second-generation Chinese of professionals in Memphis. In Cynthia Bernstein, Thomas Nunnally and Robin Sabino (eds.), Language variety in the south revisited. Tuscaloosa and London: University of Alabama Press, pp. 163-170.

Cho, Grace, Kyung-Sook Cho, and Lucy Tse (1997) Why ethnic minorities want to develop their heritage language: The case of Korean Americans. Language, Culture, and Curriculum 10.2: 106-112.

Chun, Elaine (2001) The construction of white, black, and Korean American identities through African American Vernacular English. Journal of Linguistic Anthropology 11.1: 52-64.

Crawford, James (1992) Language loyalties: A source book on the official English controversy. Chicago: University of Chicago Press.

Duff, Patsy, Ping Wong, and Margaret Early (2002) Learning language for work and life: The linguistic socialization of immigrant Canadians seeking careers in healthcare. Modern Language Journal 86: 397422.

Duranti, Alessandro, and Elinor Ochs (1997) Syncretic literacy in a Samoan American family. In Lauren B. Resnick, Roger Säljö, Clotilde Pontecorvo and Barbara Burge (eds.), Discourse, tools, and reasoning: Essays on situated cognition. Berlin: Springer, pp. 169-202.

Duranti, Alessandro, Elinor Ochs, and Elia K. Ta`ase (1995) Change and tradition in literacy instruction in a Samoan American community. Educational Foundations 9: 57-74.

Ervin-Tripp, Susan (1964) An analysis of the interaction of language, topic, and listener. American Anthropologist 66 (6, Part 2: The Ethnography of Communication): pp. 86-102.

Espiritu, Yen Le (1992) Asian American panethnicity: Bridging institutions and identities. Philadelphia: Temple University Press.

Fought, Carmen (2003) Chicano English in context. New York: Palgrave Macmillan.

Fu, Danling (1995) My trouble is my English: Asian students and the American dream. Portsmouth, NH: Boynton/Cook: Heinemann. 
Ha, Francis Inki (1995) Shame in Asian and Western cultures. American Behavioral Scientist 38.8: 11141131.

Hakuta, Kenji (1975) Learning to speak a second language: What exactly does the child learn? In Daniel P. Dato (ed.), Developmental psycholinguistics: Theory and applications. Washington, D.C.: Georgetown University Press.

Hanna, David B. (1997) Do I sound "Asian" to you?: Linguistic markers of Asian American identity. In Charles Boberg, Miriam Meyerhoff and Stephanie Strassel (eds.), University of Pennsylvania Working Papers in Linguistics. Philadelphia, PA: Department of Linguistics, University of Pennsylvania 4.2: 141153.

Hardman, Joel (1998) Literacy and bilingualism in a Cambodian community in the USA. In Aydin Yèucesan Durgunoglu and Ludo Verhoeven (eds.), Literacy development in a multilingual context: crosscultural perspectives. Mahwah, N.J.: Lawrence Erlbaum Associates, pp. 51-81.

Harklau, Linda (1994) ESL versus mainstream classes: Contrasting L2 learning environments. TESOL Quarterly 28.2: 241-272.

He, Agnes Weiyun (2001) The language of ambiguity: Practices in Chinese heritage language classes. Discourse Studies 3.1: 75-96.

Hinton, Leanne (2001) Involuntary language loss among immigrants: Asian-American linguistic autobiographies. In James E. Alatis and Ai-Hui Tan (eds.), Georgetown University Round Table on Language and Linguistics 1999. Washington, DC: Georgetown University Press, pp. 203-252.

Jo, Hye-young (2001) 'Heritage' language learning and ethnic identity: Korean Americans' struggle with language authorities. Language, Culture and Curriculum 14.1: 26-41.

Kang, M. Agnes (2003) Negotiating conflict within the constraints of social hierarchies in Korean American discourse. Journal of Sociolinguistics 7.3: 299-320.

Kang, M. Agnes, and Adrienne Lo (2003) Two ways of articulating heterogeneity in Korean-American narratives of ethnic identity. Ms.

Kleifgen, Jo Anne (2001) Assembling talk: Social alignments in the workplace. Research on Language and Social Interaction 34.3: 279-308.

Kochman, Thomas (1981) Black and white styles in conflict. Chicago: University of Chicago Press.

Kondo, Kimi (1998) Social-psychological factors affecting language maintenance: Interviews with shin nisei university students in Hawaii. Linguistics and education 9.4: 369-408.

Kroskrity, Paul V. (1993) Language, history, and identity: Ethnolinguistic studies of the Arizona Tewa. Tucson: University of Arizona Press.

Labov, William (1972) Language in the inner city: Studies in the black English vernacular. Philadelphia: University of Pennsylvania Press.

Lai, Eric Yo Ping, and Dennis Arguelles (2003) The new face of Asian Pacific America: Numbers, diversity, and change in the 21st century. San Francisco: AsianWeek books.

Leap, William L. (1993) American Indian English. Salt Lake City: University of Utah Press.

Li, Guofang (2000) Family literacy and cultural identity: An ethnographic study of a Filipino family in Canada. Mc Gill Journal of Education 35.1: 9-29. 
Li, Guofang (2002) East is east, west is west?: Home literacy, culture, and schooling. New York: Peter Lang.

Li, Guofang (forthcoming) Battles of literacy and culture: Teaching and learning in a new social order. Albany: State University of New York Press.

Li, Guofang (forthcoming) Perspectives on struggling English language learners: Case studies of two Chinese-Canadian children. Journal of Literacy Research.

Lindemann, Stephanie (2003) Koreans, Chinese, or Indians? Attitudes and ideologies about non-native English speakers in the United States. Journal of Sociolinguistics 7.3: 348-364.

Lo, Adrienne (1999) Codeswitching, speech community membership, and the construction of ethnic identity. Journal of Sociolinguistics 3: 461-479.

Lowe, Lisa (1996) Immigrant acts: On Asian American cultural politics. Durham: Duke University Press.

Manalansan, Martin F. (1995) "Performing" Filipino gay experiences: Linguistic strategies in a transnational context. In William Leap (ed.), Beyond the lavender lexicon: Authenticity, imagination, and appropriation in lesbian and gay languages. Amsterdam: Gordon and Breach, pp. 249-266.

Mendoza-Denton, Norma, and Melissa Iwai (1993) "They speak more Caucasian": Generational differences in the speech of Japanese-Americans. In Robin Queen and Rusty Barrett (eds.), Proceedings of the first annual symposium about language and society - Austin. Austin: University of Texas 33: 58-67.

Mitchell-Kernan, Claudia L. (1972) Signifying and marking: Two Afro-American speech acts. In John J. Gumperz and Dell Hymes (eds.), Directions in sociolinguistics. New York: Blackwell, pp. 161-179.

Morgan, Marcyliena H. (2002) Language, discourse and power in African American culture. Cambridge; UK/New York: Cambridge University Press.

Needham, Susan (2003) "This is active learning": Theories of language, learning, and social relations in the transmission of Khmer literacy. Anthropology and Education Quarterly 34.1: 27-49.

Nishimura, Miwa (1997) Japanese/English code-switching: Syntax and pragmatics. New York: Peter Lang.

Ong, Aihwa, and Donald Nonini (1997) Ungrounded empires: The cultural politics of modern Chinese transnationalism. New York: Routledge.

Penfield, Joyce, and Jacob L. Ornstein-Galicia (1985) Chicano English: An ethnic contact dialect. Amsterday; Philadelphia: John Benjamins.

Philips, Susan Urmston (1983) The invisible culture: Communication in classroom and community on the Warm Springs Indian reservation. New York: Longman.

Pon, Gordon, Tara Goldstein, and Sandra R. Schecter (2003) Interrupted silences: The contemporary education of Hong Kong-born Chinese Canadians. In Robert Bayley and Sandra R. Schecter (eds.), Language socialization in bilingual and multilingual societies. Clevedon, UK: Multilingual Matters, pp. 114-127

Rampton, Ben (1995) Crossing: Language and ethnicity among adolescents. New York: Longman.

Reinecke, John E. (1969) Language and dialect in Hawaii: A sociolinguistic history to 1935. Stanley Tsuzaki (ed.). Honolulu: University of Hawaii Press.

Reyes, Angela (2002) "Are you losing your culture?": Poetics, indexicality and Asian American identity. Discourse Studies 4: 183-200. 
Romaine, Suzanne (1994) Hawaii Creole English as a literary language. Language in Society 23: 527554.

Romaine, Suzanne (1999) Changing attitudes towards Hawai‘i Creole English: Fo' get one good job, you gotta know ho fo' talk like one haole. In John Rickford and Suzanne Romaine (eds.), Creole genesis, attitudes and discourse. Amsterdam: John Benjamins, pp. 287- 301.

Romaine, Suzanne (2002) Signs of identity, signs of discord: Glottal goofs and the green grocer's glottal in debates on Hawaiian orthography. Journal of Linguistic Anthropology 12.2: 189-225.

Sato, Charlene (1985) Linguistic inequality in Hawai‘i: The post-Creole dilemma. In Nessa Wolfson and Joan Manes (eds.), Language of inequality. Berlin; New York: Mouton, pp. 255-272.

Sato, Charlene (1991) Sociolinguistic variation and language attitudes in Hawai'i. In Jenny Cheshire (ed.), English around the world: Sociolinguistic perspectives. Cambridge/New York: Cambridge University Press, pp. 647-663.

Scarcella, Robin, and Kusup Chin (1993) Literacy practices in two Korean-American communities. Research Report: 8. National Center for Research on Cultural Diversity and Second Language Learning, Santa Cruz, CA.

Schmidt, Richard (1983) Interaction, acculturation, and the acquisition of communicative competence: A case study of an adult. In Nessa Wolfson and Elliott Judd (eds.), Sociolinguistics and language acquisition. Rowley, MA: Newbury House, pp. 137-174.

Shin, Sarah J., and Lesley Milroy (2000) Conversational codeswitching among Korean-English bilingual children. International Journal of Bilingualism 4.3: 351-383.

Skilton-Sylvester, Ellen (2002) Literate at home but not at school: A Cambodian girl's journey from playwright to struggling writer. In Glynda A. Hull and Katherine Schultz (eds.), School's out! Bridging out-of-school literacies with classroom practice. New York: Teachers College Press, pp. 61-90.

Spencer, Robert (1950) Japanese American language behavior. American Speech 241-252.

Sridhar, Kamal K. (1988) Language maintenance and language shift among Asian-Indians: Kannadigas in the New York area. International Journal of Sociology of Language 69: 73-87.

Tuan, Mia (1998) Forever foreigners or honorary whites?: The Asian ethnic experience today. New Brunswick, NJ: Rutgers University Press.

Tuc, Ho-Dac (2003) Vietnamese-English bilingualism: Patterns of code-switching. London; New York: RoutledgeCurzon.

Wei, Li (1994) Three generations, two languages, one family: Language choice and language shift in a Chinese community in Britain. Clevedon; Philadelphia: Multilingual Matters.

Weinstein-Shr, Gail (1993) Literacy and social process: A community in transition. In Brian Street (ed.), Cross-cultural approaches to literacy. Cambridge: Cambridge University Press, pp. 272-293.

Yoon, Keumsil Kim (1992) New perspective on intrasentential code-Switching: A Study of KoreanEnglish switching. Applied Psycholinguistics 13.4: 433-449.

Yoon, Keumsil Kim (1996) A case study of fluent Korean-English bilingual speakers: Group membership and code choices. Journal of Pragmatics 25.3: 395-407.

Zentella, Ana Celia (1997) Growing up bilingual: Puerto Rican children in New York. Malden, MA: Blackwell Publishers. 
Zhou, Min, and Carl L. Bankston (1998) Growing up American: How Vietnamese children adapt to life in the United States. New York: Russell Sage Foundation. 